\title{
Effect of Storage on Performance of Super Nickel-cadmium Cells
}

\author{
Hari Vaidyanathan \\ COMSAT Laboratories \\ Clarksburg, MD 20871 \\ and \\ Gopalakrishna M. Rao \\ NASA-Goddard Space Flight Center \\ Space Power Applications Branch \\ Greenbelt, MD 20771
}

\begin{abstract}
A study was undertaken to examine the capacity maintenance features of SUPER nickelcadmium cells when stored for extended periods to determine whether the features change when the same kinds of positive plates as that used in nickel-hydrogen cells are used. The cells inaintained their capacity when stored at $0^{\circ} \mathrm{C}$ in the discharged state and at $0^{\circ} \mathrm{C}$ in the charged state by continuously trickle charging. There was a capacity loss when stored in the open-ciruit condition at $28^{\circ} \mathrm{C}$. A cycling test at $17 \%$ depth of discharge for 2400 cycles using cells stored at various conditions showed that cells maintained good end of discharge voltage regardless of their storage history. However, the EOD voltages of stored cells were lower by $10 \mathrm{mV}$ compared to those of tresh cells. The capacity at the end of the cycling test decreased for the stored cells by $2-7$ Ah. The storage related capacity loss is lower for SUPER $\mathrm{Ni}-\mathrm{Cd}$ cells compared to that of $\mathrm{Ni}-\mathrm{H}_{2}$ cells containing a hydrogen precharge. The results suggest the pivotal role of hydrogen pressure in the capacity loss phenomenon.
\end{abstract}

\section{INTRODUCTION}

The nickel-cadmium battery, introduced in the late mid-sixties as the energy storage device in orbiting satellites has steadily evolved into a reliable power source with excellent voltage maintenance with cycling. This battery has been extensively studied and matters relating to electrode reaclions, overcharge and overdischarge, capacity balance between the electrodes, precharge, overcharge protection, electrolyte content and pulse behavior are better understood. However, several questions have arisen in the recent past about capacity stability with cycling, high end of charge voltages and capacity loss when storect for extended periods. The capacity loss phenomenon with extended storage has drawn the attention of the aerospace industry since the battery is expected to be capable of storage for 60 months after fabrication so that launch clelays could be accommodated. A related issue is the capacity recovery technique studicu by various organizations. There is agreement among various researchers that the capacity loss phenomenon is attributable to the nickel hydroxicte positive plates, although, opinions differ about the capacity 
fade inechanism. Capacity fading in nickel-hydrogen cells is attributed to cobalt by Zimmermall (1). dehydration by Vaidyanathan (2,3), and platinum hydroxide by Whitely (4)

The capacity fade phenomenon first surfaced in 1986 for nickel-hydrogen cells. Studies showed that cells with aqueous impregnated positive plates, alcohol impregnated positive plates, nickel pre-charge cells and hydrogen precharge cells are susceptible to capacity luss to varying, degrees Attempts to quantify the capacity fade has been unsuccessful since the loss is not a linear functom of time and cells that exhibit capacity fading show poor reproducibility in the capacily values from one cycle to the next. Thus, the cells that do not show capacity fading in the beginning of life change their behavior after a combination of inactivity and cycling and vire versa. All this shows that it is difficult to predict capacity fading from looking at the storage conditions. The purpose of this study is to determine whether capacity fading occurs in SUPER. Vi-Cd cells which contain electrochemically impregnated plates when stored at various temperatures and in the trickle charge mode. Another objective is to determine the cycling behavior of cells subjected to extended storage. The SUPER Ni-Cd cells contain positive plates similar in structure and composition to that used in $\mathrm{Ni}-\mathrm{H}_{2}$ cells and hence the results of this study would establish the role of hydrogen pressure in capacity fade phenomenon.

\section{Cell Selection}

The cells were selected from two different groups of cells manufactured for NASA-Goddard Space Flight center by Hughes/Eagle Picher and their design conformed to the general specifications for a SUPER Ni-Cd cell. The cells contain sintered and electrochenically impregnated positive plates using the alcohol process which are similar to those used in $\mathrm{Ni}-\mathrm{H}_{2}$ cells. The negative plates are sintered and electrochemically impregnated using the aqueous process. The first group of cells were rated at $20 \mathrm{Ah}$ and the second at $50 \mathrm{Ah}$. Table 1 shows the design features of the cells.

\section{Capacity loss at $0^{\circ} \mathrm{C}$ storage}

A group of 3 cells was stored at $0^{\circ} \mathrm{C}$ in the discharged open-circuited condition for 30 days and another group of 2 for 60 days. The capacity and average voltage during discharge at $20^{\circ} \mathrm{C}$ at $\mathrm{C} / 2$ were compared before and after storage and are shown in Table 2 . The first group after 30 days showed marginal changes in the capacity (to $1 \mathrm{~V}$ ) with one cell showing a small increase, while the total capacity increased $0.7-3 \%$. The second group of cells showed an increase of $6-7.6 \%$ in the total capacity after 60 days but with a decrease of $1-2 \%$ in the capacity to $1 \mathrm{~V}$

The aid-discharge voltages of the cells are included in Table 2 and they show that after the 30 day storage period the mid-discharge voltage increased by $4-7 \mathrm{mV}$ and after the 60 -day storage the increase was $1-8 \mathrm{mV}$. The changes observed in the capacity and voltage are marginal and the results suggest that the cells maintain their capacity and voltage when stored at $0^{\circ} \mathrm{C}$.

\section{Capacity loss in the trickle charge storage}

Groups of 3 cells were charged at C/10 for 16 hours and then trickle charged at C/100 for 30 days at $0^{\circ} \mathrm{C}$. Table 3 shows the initial capacity and the capacity after 30 days. There was a marginal loss of $1.3-2.7 \%$ in the capacity to $1 \mathrm{~V}$ and an increase of $2.3-5.3 \%$ in total capacity as a result of the trickle charge.

The same cells were then subjected to trickle charge storage for 60 days under the same conditions. Table 3 shows the capacity values after the storage. The cell capacity increased by 0.1 Ah for one of the cells and the other cells showed a marginal loss of 0.1 Ah to $1 \mathrm{~V}$. The total capacity increased by $6-8 \%$. 
Table 3 also shows the mid-discharge voltages, which in the case of 30-day trickle charge increased by $3-7 \mathrm{mV}$. At the end of the 60-day trickle charge, the incrcase over the initial values was $1.6 \mathrm{mV}$. The results suggest that trickle charge storage is appropriate for these cells.

\section{Capacity maintenance in a combined $0^{\circ} \mathrm{C}$ and trickle charge}

A group of 5 cells was stored in the following sequence-trickle charge at $O C$ for 30 days, opencircuit for 30 days at $0^{\circ} \mathrm{C}$, trickle charge for 60 days at $0^{\circ} \mathrm{C}$ another group in the sequence-opencircuit at $0^{\circ} \mathrm{C}$. trickle charge for 30 days at $0^{\circ} \mathrm{C}$ and open-circuit for 60 days at $0^{\circ} \mathrm{C}$. The capacity maintenance values were compared. The capacity to $1 \mathrm{~V}$ decreased by $0.4-2.1 \%$ and the total capacity increased by $4-8 \%$. The magnitude of change in the capacity to $1 \mathrm{~V}$ is not significant, therefore, a technique consisting of open-circuit storage followed by trickle charge or vice versa to store cells is also appropriate.

\section{Capacity loss at $28^{\circ} \mathrm{C}$ storage}

Two 50 Ah cells was stored at $28^{\circ} \mathrm{C}$ in the open circuit condition for 30 days and the capacity was determined. The cells were then stored for another 30 day at $28^{\circ} \mathrm{C}$. The cell capacities were determined and values are shown in Table 5. After the first 30-days the cells showed losses in capacity (lo $1 \mathrm{~V}$ ) at $0^{\circ}, 10^{\circ}$ and $20^{\circ} \mathrm{C}$. However, after the second 30 -day storage both the cells showed a loss of $3.4 \mathrm{Ah}$ in capacity in the $20^{\circ} \mathrm{C}$ test. In the $10^{\circ} \mathrm{C}$ and $0^{\circ} \mathrm{C}$ test one cell showed a decline of $0.8 \mathrm{Ah}$ and the other cell showed a marginal increase. The results suggest that the cells are susceptible to capacity loss when stored at $28 \mathrm{C}$. The reversal of the trend after the first 30-day storage indicates the difficulty in generalizing the capacity loss phenomenon. The mid-discharge voltage showed an improvement for both the cells after the storage periods as shown in Table 5 . The storage behavior of $\mathrm{Ni}-\mathrm{Cd}$ cells at $28^{\circ} \mathrm{C}$ can be compared to that of nickel precharge and hydrogen precharge $\mathrm{Ni}_{-} \mathrm{H}_{2}$ cells. An earlier study indicatect that the $10^{\circ} \mathrm{C}$ ca pacity decreased by $23 \%$ in 52 days of storage for the nickel precharge cells and by $35 \%$ for the hydrogen precharge cells(2). The decline in the $20^{\circ} \mathrm{C}$ capacity obtained for the Ni-Cd cells is $5.7 \%$ which is marginal when compared to that obtained for nickel-hydrogen cells. This observation brings forth the role of hydrogen pressure in the capacity fading mechanism. Since the cadmium electrode is believed to generate minute quantities of hydrogen that is a function of negative electrode structure, composition, temperature, $\mathrm{KOH}$ concentration and age, the $\mathrm{Ni}-\mathrm{Cd}$ cells are not hydrogen free. Therefore, it is not the presence of hydrogen but it's quantity that is important in capacity fading.

\section{Cycling behavior of cells stored at $0^{\circ}, 10^{\circ}$ and $28^{\circ} \mathrm{C}$}

The initial capacity of 3 pairs of cells was deternuined first and thenthe cells were stored a pair at $0^{\circ} \mathrm{C}$, another at $10^{\circ} \mathrm{C}$ and the third at $28^{\circ} \mathrm{C}$. The storage sequence consisted of capacity discharge, resistive drain, storage in the open-circuit condition for 3-days, capacity determination, resistive discharge and finally storage for another 30 day. The cell capacities were again determined. A cycling test was started which mimics the load, temperature and charge profile for a low earth orbit satellite. The cells were cycled continuously at $17 \%$ depth of discharge with an overcharge of $7 \%$ in a regime consisting of discharge for 26 minutes at $20 \mathrm{~A}$ and charge at $16 \mathrm{~A}$ for 70 minutes. The cells maintained good discharge voltage and after 2379 cycles the value was 1.210 1.213 Vfor the end of discharge voltage as shown in Figure 1. There was no significant difference in the end of discharge voltage for the cells that showed a loss in capacity as result of storage at $28^{\circ} \mathrm{C}$. It is possible that capacity recovery occurred for the cells stored at $28^{\circ} \mathrm{C}$ as a result of cycling. Figure 1 also includes the variation of end of discharge voltage for a group of fresh cells cycled at $25 \%$ depth of discharge. The end of discharge voltages of the fresh cells is higher by 10 $\mathrm{mV}$ at every cycle compared to the stored cells in spite of the fact that the depth of discharge is $25 \%$ as opposed to $17 \%$. Thus, the storage has an effect on cycling behavior, but quantitatively the effect is marginal. The cell capacities were determined at the end of 2400 cycles and the results are 
shown in Table 6 . There was a capacity loss of 2-6 Ah for the cells. The cells stured at $28^{\circ} \mathrm{C}$ showed the maximum decline. The mid-discharge voltage during discharge at $\mathrm{C} / 2$ at $10^{\circ} \mathrm{C}$ was 1.229-1.239 $\mathrm{V}$ which represents no change in the behavior. Thus, the limited cycling test data suggests that there is some degradation as a result of storage but the effect of storagc on cell performance is marginal. An extencled cycling data on the stured cells is needed to verify this observation.

\section{CONCLUSIONS}

The results of the study on extended storage of SUPER nickel-cadmiun cells suggest the following conclusions;

- cells maintain their capacity if stored at $0^{\circ} \mathrm{C}$

- cells maintain their capacity if stored in the trickle charge mode at $0^{\circ} \mathrm{C}$

- There is a capacity loss if stored at $28^{\circ} \mathrm{C}$, but the decline is maryinal compared to that obtained in $\mathrm{Ni}_{-} \mathrm{H}_{2}$ cells, thereby indicating the increased susceptibility of the positive plates to exhibit capacity fading when hydrogen pressure is high

- Cells stored for 2 months when cycled show marginal decrease in the end of discharge voltage and capacity

\section{REFERENCES}

1. Zimmerman, A.,"Mechanism for Capacity Fading in $\mathrm{Ni}_{-} \mathrm{H}_{2}$ Cells and It's Effect on Cycle Life,"NASA Aerospace Battery Workshop, Marshall Space Flight Center, Huntsville, Alabama, 1992, Proc.,NASA Conference-Publication No. 3192

2 Vaidyanathan, H., "Long-Term Storage Of Nickel-hydrogen Cells", J. Power Sources, 1988. Vol., 221-228

3. Whitely, R.V., and Gibney, A.,"Storage Considerations for Ni-H2 Battery Cells", NASA/GSFC Battery Workshop, Goddard Space flight Center, Greenbelt, Maryland, March 1988

4. Vaidyanathan, H.," Distinctive Features of Storage-Induced Capacity Loss in Ni- $\mathrm{H}_{2}$ Cells" IECEC Conference, Atlanta, GA 1993, American Chemical society, Proc. Vol. 3, 131-136 
TABLE 1: CELL DESIGN FEATURES OF THE SUPER Ni-Cd CELLS

Components

Rated Capacity
Activation Date
Interelectrode spacing
Electrolyte

Separator

Positive Plates

Negative Plates
Parameters

$21 \mathrm{Ah}$ and $50 \mathrm{Ah}$

21 Ah-Spring 1995

50 Ah-Fall 1994

approximately 10 mils

$31 \% \mathrm{KOH}$-Theoretical

approx. $24 \% \mathrm{KOH}$-actual

approx. $10 \% \mathrm{~K}_{2} \mathrm{CO}_{3}$-actual

Zircar separator coated with PBI

Alcoholic electochemically deposited approx. $1.3 \mathrm{~g}$ active $\mathrm{Ni} / \mathrm{Cc}$ void volume approx. $100 \%$ plate utilization

Aqueous electrochemically deposited approx. $12 \mathrm{~g} \mathrm{Cd} / \mathrm{dm}^{\wedge} 2$

approx. $70 \%$ plate utilization 


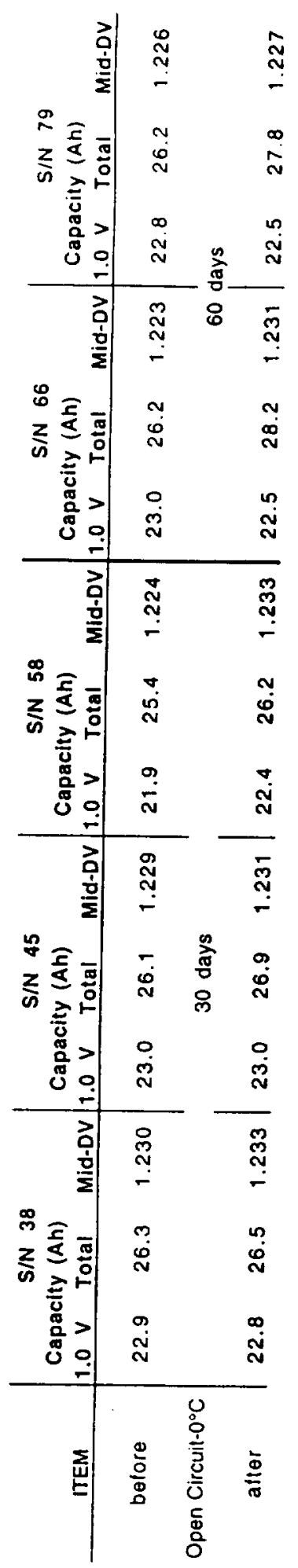




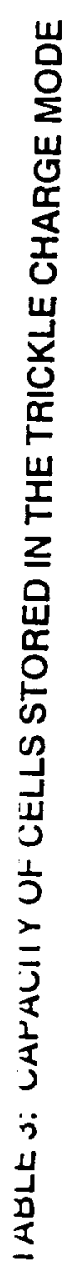

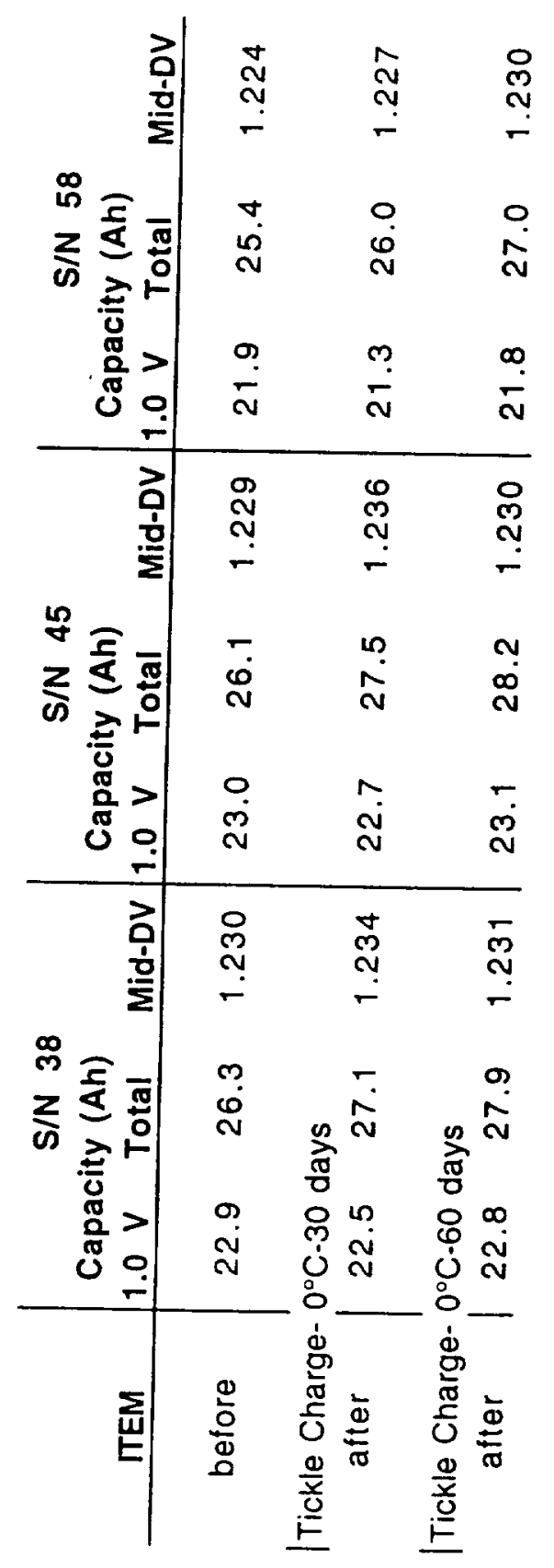




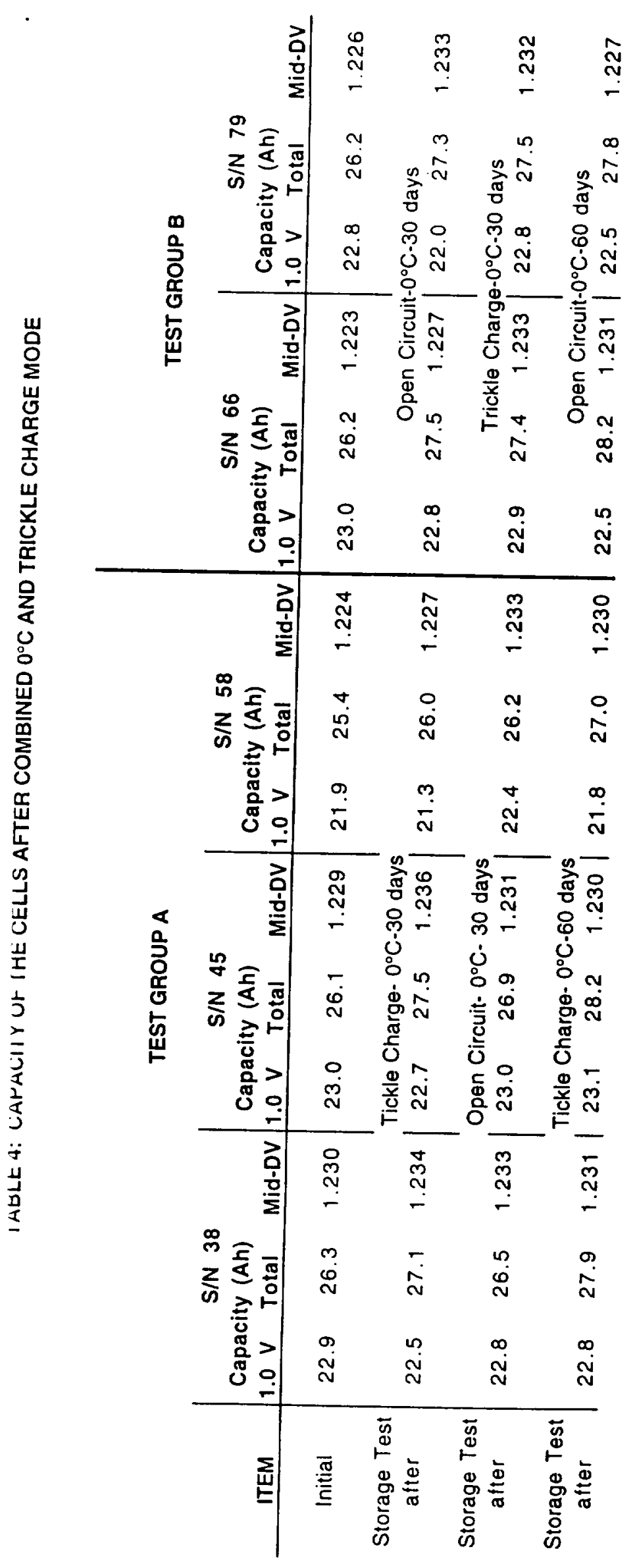




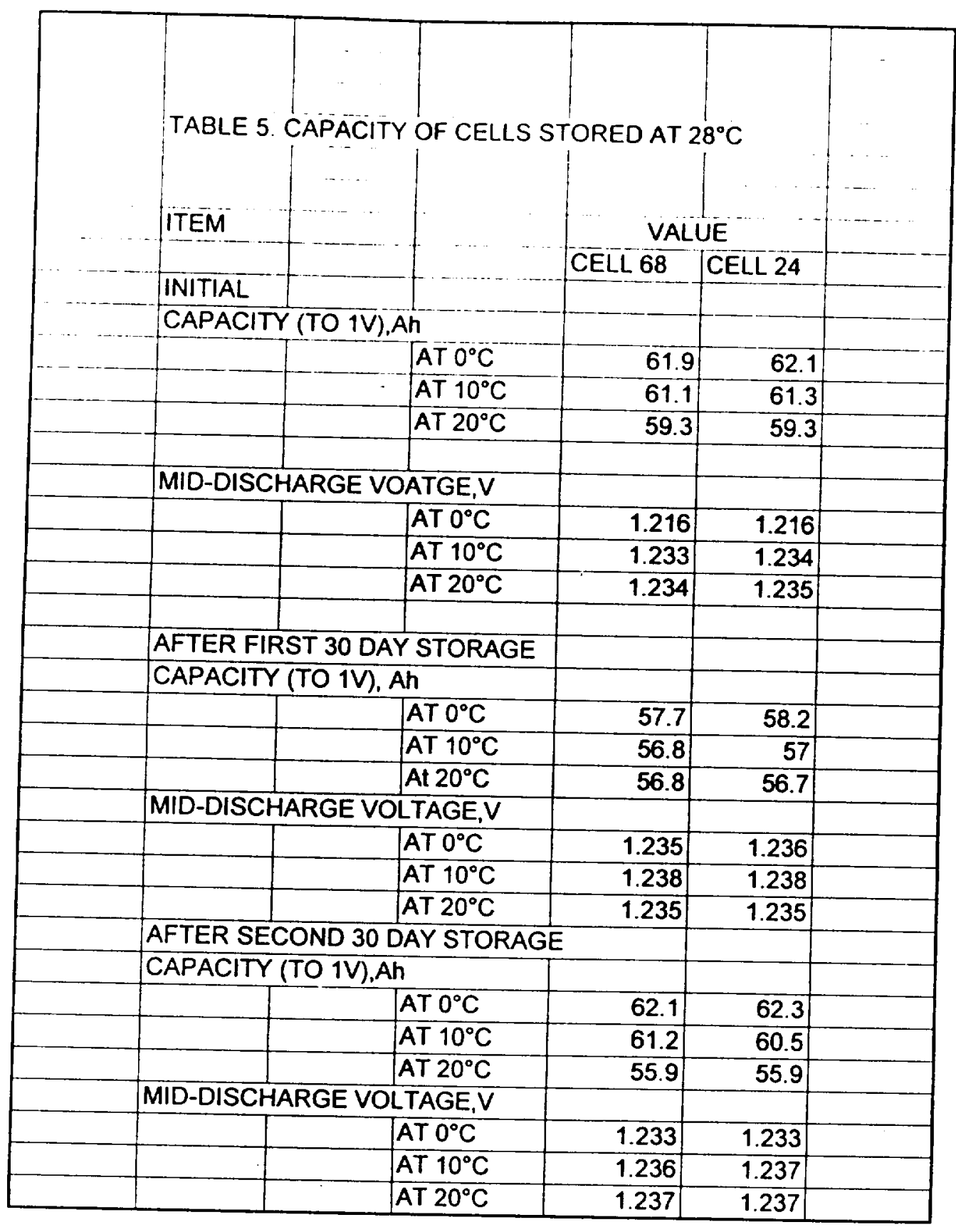




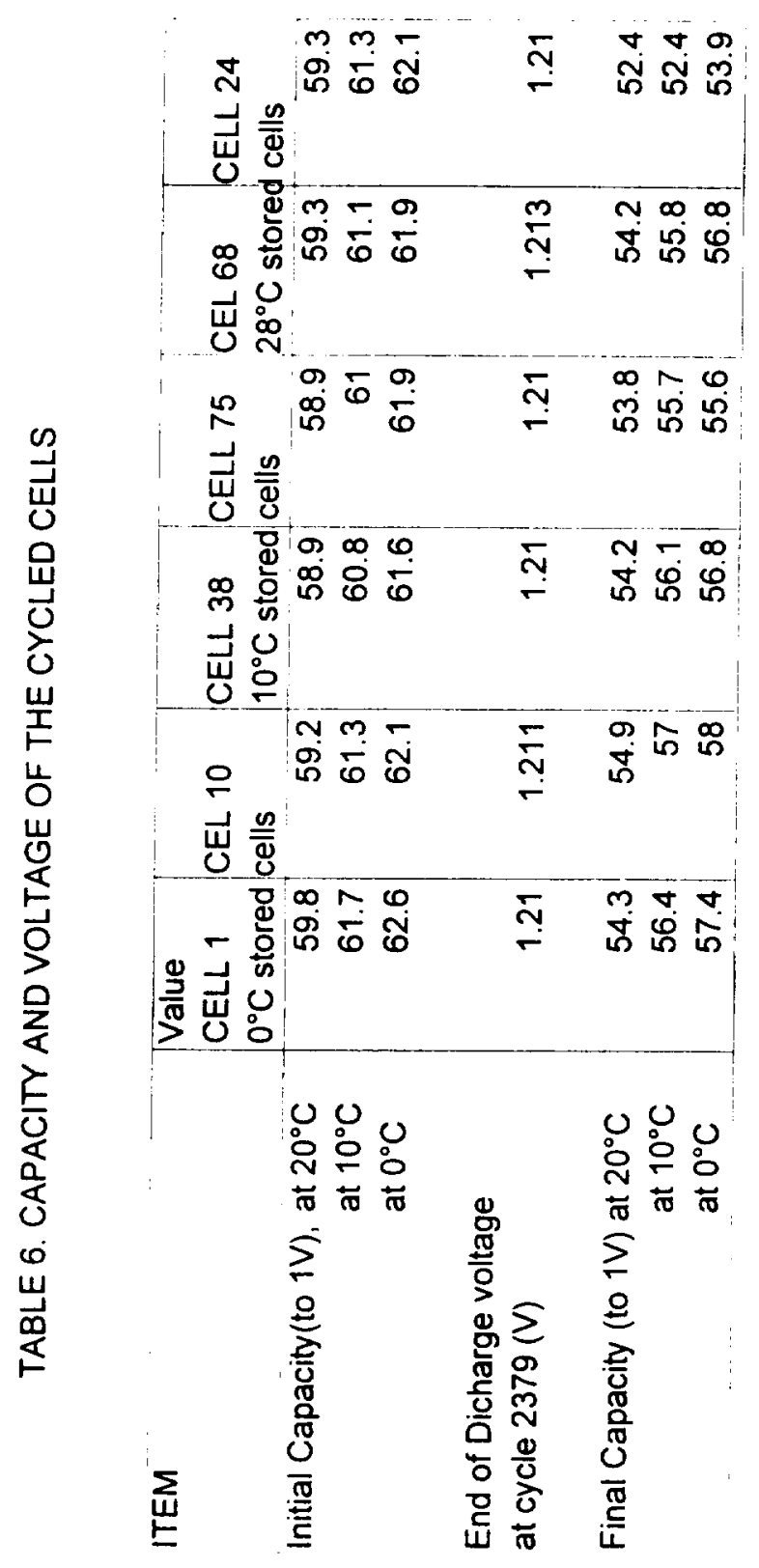




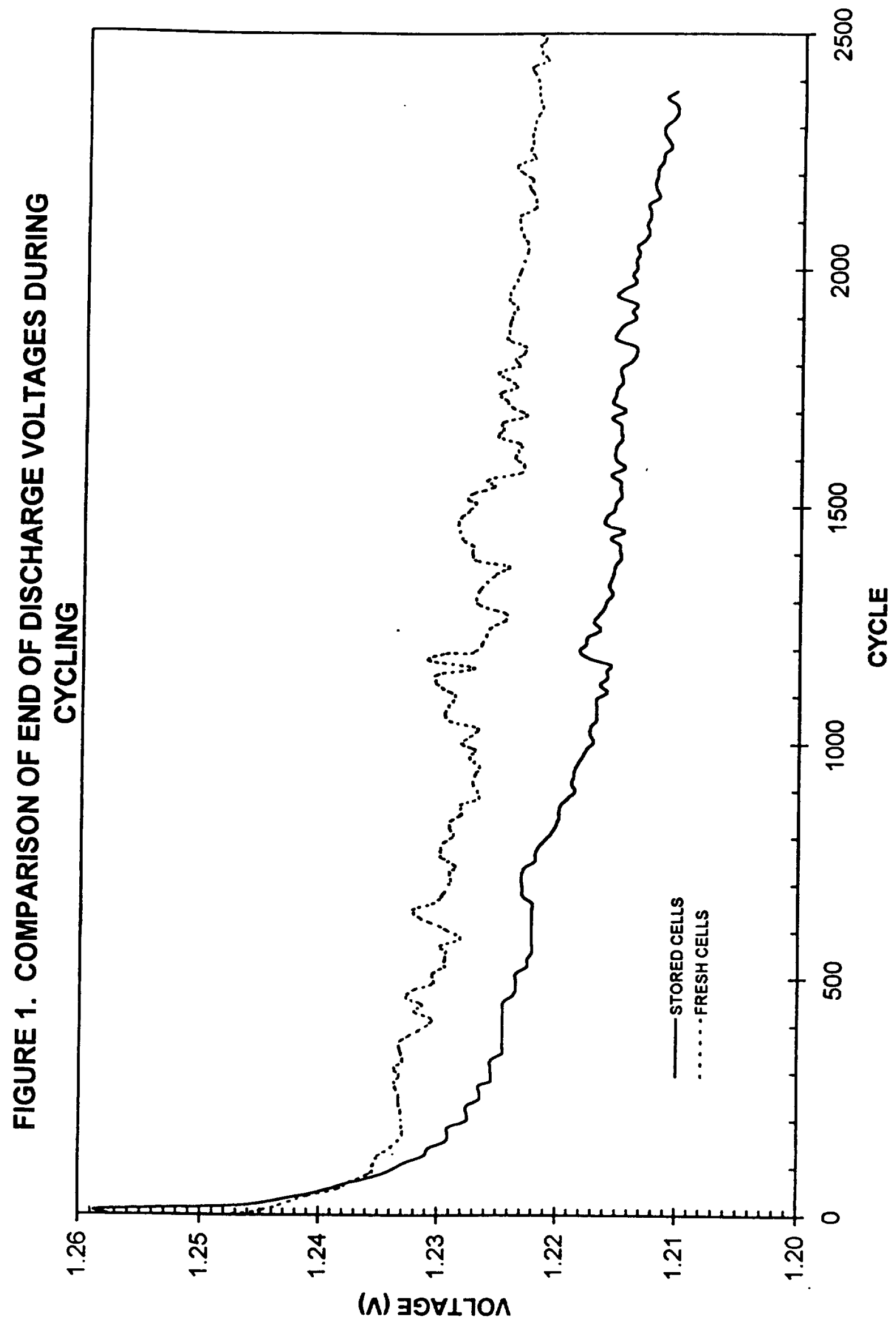

